\title{
1. A brief description of the crisis
}

Instead of an aristocracy of the merely rich, we are moving to an aristocracy of the capable and the rich. The financial revolution is opening the gates of the aristocratic clubs to everyone. In this respect, the financial revolution is thoroughly liberal in spirit. Instead of capital, it puts the human being at the center of economic activity because, when capital is freely available, it is skills, ideas, hard work, and inescapably, luck that create wealth. (Raghuram Rajan and Luigi Zingales 2003c, p. 92)

The problem, or at least a significant part of it, is the rising political hegemony of the financial sector. ... The financial sector has increasingly been able to rig the rules to its own advantage. This has damaged not only the economy but the financial sector itself. (Luigi Zingales 2012, p. 49)

This chapter briefly describes the key characteristics of the contemporary crisis. The first characteristic is related to the place where the crisis originated. The second concerns the phenomenon that triggered it, that is, the substantial increase in delinquencies in a specific category of residential mortgages, namely, the so-called subprime mortgages. The third characteristic has to do with the evolution of the crisis since 2007.

\section{THE OUTBREAK OF THE FINANCIAL CRISIS IN THE UNITED STATES}

The financial crisis that caused the Great Recession erupted in the United States, the country with the world's most advanced financial system, a system that in recent decades had undergone an intense process of innovation and was taken as the benchmark that other countries should strive to replicate. The textbooks define the financial system as the complex structure of markets, institutions and instruments used to facilitate the transfer of funds from lenders to borrowers. It is a particularly dynamic structure due to innovations that change the features of the financial instruments, markets and intermediaries.

Economists have singled out different criteria that enable measurement of the degree of development of financial structures. ${ }^{1}$ Rajan and Zingales (2003a, 2003b, 2003c) set a standard based on the concept of innovation, 
which takes on a central role in Schumpeter's work. Schumpeter (1912 [1949]) emphasizes that the fundamental characteristic of a capitalist economy is the process of change led by the innovations introduced by entrepreneurs. According to Rajan and Zingales, the degree of development of the financial system can be defined in relation to its ability to finance innovations. Hence, they claim that a financial system is highly sophisticated if it is capable of financing innovations, while it should be considered underdeveloped when it fails to fulfil this function.

To better understand the meaning of this classification, another aspect of Schumpeter's analysis should be taken into account. Schumpeter remarks that usually innovations are not introduced by existing companies, but by new subjects with special skills, other than those needed to manage an existing business. The introduction of an innovation breaks the equilibrium underpinning the normal trend of the economic process. An entrepreneur who is willing to introduce an innovation must therefore be ready to face resistance from those who, for social and economic reasons, oppose his choices. Recalling these elements of Schumpeter's analysis, Rajan and Zingales conclude that a developed financial system must be able to support new entrepreneurs by considering the characteristics of their investment projects independently of other elements, such as their family and personal relationships. ${ }^{2}$

Rajan and Zingales also believe that a financial system in which banks play a central role, known as a relation-based financial system, is a typical example of an underdeveloped financial system. In fact, in their opinion such a system is unable to finance innovations as banks tend to focus only on borrowers they know directly or that can offer sound guarantees. Moreover, given the relationships that they maintain with existing businesses, banks are less willing to finance innovations that could affect their customers' profitability. In contrast, a well-developed financial system, which Rajan and Zingales define as an arm's length system, is based on market relationships and is characterized by the presence of a multiplicity of subjects that can extend credit. According to Rajan and Zingales, in this type of system an entrepreneur-innovator without sufficient collateral has a better chance of getting a loan, since he can contact a larger number of potential lenders that will evaluate his investment project independently of each other.

The two authors underline that, due to the profound changes that had occurred since the 1980s, the American financial system represented an important example of an advanced financial structure that is highly suitable for financing innovations, while the financial systems of the European countries, still overly bank based, were typical examples of 
underdeveloped systems. Rajan and Zingales's analysis raises the question of how the financial crisis of 2007 could originate in the very system that was regarded as the most advanced in the world. ${ }^{3}$

\section{THE CRISIS IN THE SUBPRIME MORTGAGE MARKET}

The financial crisis erupted in the spring of 2007, when a major increase in default rates of residential mortgages, and particularly subprime mortgages, was recorded in the US housing market. In the United States there are two categories of residential mortgages, namely prime and non-prime mortgages. Prime mortgages meet certain conditions regarding the ratio between the loan amount and the value of the house (loan to value rate) and the ratio between the loan amount and the borrower's income (loan to income rate). Conversely, non-prime mortgages do not meet these conditions and are divided into three categories: Alt-A mortgages granted to borrowers who do not meet all the necessary criteria for receiving prime mortgages; Home Equity Line Of Credit (HELOC) mortgages, characterized by the assignment of a line of credit that cannot exceed a certain amount and must be used in a given timeframe; and finally subprime mortgages, granted to borrowers with low income and no capital endowment. Most of the subprime loans originated before the eruption of the crisis and comprised adjustable rate mortgages which, in accordance with the $2 / 28$ or $3 / 27$ formula, provided for the payment of interest rates that were so low as to be called teaser loans for the first two or three years, and the payment of much higher rates for the remaining 28 or 27 years of the contract. Another class of subprime mortgages that became notorious after the onset of the crisis consisted of loans offered to people with no income, no job and no assets (ninja loans).

The crisis occurred at the end of a period in which the US financial system had greatly increased the supply of mortgages. In six years, from the end of 2000 to the end of 2006, the number of mortgages more than doubled, reaching an astonishing value of 11 trillion dollars. The increase in supply was coupled with a significant deterioration in the quality of the loans. In fact, the share of non-prime mortgages increased from 14 per cent in 2001 to 48 per cent in 2006. Correspondingly, the share of subprime mortgages increased from 5 per cent in 2001 to 20.1 per cent in 2006 (Jaffee et al. 2009). This caused an unprecedented weakening of the mortgage market. 
The drastic surge of defaults that triggered the crisis was linked to an increase in the federal funds rate, that is, the rate at which the Federal Reserve finances the US banking system, which affects the entire term structure of interest rates. After the stock market crash of 2000 and the terrorist attacks on the Twin Towers on 11 September 2001, the Federal Reserve slashed the federal funds rate. From a value of over 6 per cent in 2000, the rate dropped to 2 per cent in 2001 and 1 per cent in 2003. As in the early months of 2004 the recession seemed averted, the US monetary authorities began to progressively increase the federal funds rate, which reached 4 per cent in 2004 and 5.25 per cent in 2006. This drift explains the increase in defaults by borrowers, especially by those who, at the time when interest rates decreased, had signed adjustable rate loan agreements.

\section{THE THREE PHASES OF THE CRISIS}

The crisis broke out in the summer of 2007, when the effects of defaults by borrowers struck the financial institutions that were most involved in the mortgage market. The first dramatic case was that of the British bank Northern Rock, which in September 2007 was hit by a real bank run. Another striking episode involved Bear Stearns, one of the most important American investment banks, which in the spring of 2008 did not go bankrupt thanks only to the intervention of the Federal Reserve.

During the first phase of the crisis, the monetary authorities were convinced that they were faced with a limited phenomenon that affected a significant but secondary segment of the financial system. However, the situation worsened in the summer of 2008, when the dramatic effects of the collapse of the mortgage market on the two major US mortgage agencies, Fannie Mae and Freddie Mac, were announced. These two institutions were also rescued by the US government. A few days later, the threat of insolvency hit another major US investment bank, namely Lehman Brothers. This time, contrary to its actions in the spring with the bailout of Bear Stearns, the US government did not intervene and let Lehman Brothers go bankrupt.

The bankruptcy of Lehman Brothers marked the beginning of the second phase of the crisis. It spread a deep uncertainty about the true conditions of banks and other financial institutions that paralysed the functioning of the interbank markets. This paralysis caused a remarkable rise in interest rates. The spread between the three-month interbank rate and the official rates charged by major central banks reached unprecedented levels. In just a few days, it increased from 87 to 364 basis 
points for the dollar, from 63 to 205 basis points for the euro, and from 75 to 215 basis points for the pound. In the United States, a few days after the collapse of Lehman Brothers, the government stepped in to save AIG, one of the world's largest insurance companies, while a reluctant Congress approved the TARP (Troubled Assets Relief Program), which provided for an allocation of 700 billion dollars to address the financial crisis.

The serious difficulties of the US financial system had severe repercussions in the economies around the world. Between 2007 and 2009, the world economy underwent the worst recession since the end of World War II. US per capita GDP recorded a decline of 7.2 per cent as compared with an average of 4.4 per cent experienced during previous recessions. Much greater decreases were observed in other countries such as Canada ( -8.6 per cent), Italy ( -9.8 per cent), Japan ( -8.9 per cent) and Great Britain (-9.8 per cent) (Ohanian 2010).

Government interventions aimed at supporting the international financial system and mitigating the effects of the recession caused a significant deterioration in public finances. Thus, the third phase of the crisis began, and the default risk was no longer limited to banks but also affected sovereign states. The problem of sovereign debt became particularly severe in Eurozone countries. While in these countries the annual public deficit to GDP average ratio was 1.9 per cent in the 2000-2008 period, it rose to 6.3 per cent in 2009 and was 6.2 per cent in 2010. In Germany, the budget deficit to GDP ratio rose from an average of 2.3 per cent in 2000-2008 to 3.1 per cent in 2009 and 4.1 per cent in 2010; in France, it grew from 2.7 per cent in 2000-2008 to 7.5 per cent in 2009 and 7.1 per cent in 2010; in Italy the deficit to GDP average ratio increased from 2.9 per cent in the 2000-2008 period to 5.4 per cent in 2009 and 4.5 per cent in 2010; and finally, in Britain, it increased from 2.1 per cent in $2000-2008$ to 11.5 per cent in 2009 and 10.1 per cent in 2010 .

As from 2011, the growth of sovereign debts pushed the Eurozone countries to adopt austerity policies aimed at reducing their budget deficits. In March 2012, the EU countries, with the exception only of the UK and the Czech Republic, signed the Treaty on Stability, Coordination and Governance in the Economic and Monetary Union. A tax-related section of the Treaty, which became known as the fiscal compact, provides for the mandatory introduction of the constraint of a balanced budget and an automatically triggered correction mechanism at a national level. Moreover, countries with a government debt to GDP ratio exceeding 60 per cent are required to reduce the excess of the threshold value by one-twentieth per year. 


\section{SOME QUESTIONS}

This brief review of the most important aspects of the Great Recession raises a number of questions. The first concerns the explanation of how the crisis could erupt in the country with the world's most advanced financial system. A system that, according to the analysis made by Rajan and Zingales, was the most appropriate to finance innovations and thus to facilitate the process of economic development. Residential mortgages can certainly not be considered as examples of innovation. It is therefore necessary to investigate the reasons why the American financial system began to provide mortgage loans instead of investing in innovations.

Secondly, it would be appropriate to establish the origin of the liquidity that allowed US banks to consistently expand their supply of mortgages. As pointed out above, in the 2000-2006 period, the sharp increase in mortgage supply was coupled with a marked deterioration in their quality. This raises a further question about the reasons that led banks to grant mortgage loans to families that were not able to pay them back. The fourth question concerns the behaviour of borrowers. Indeed, while banks unquestionably granted an excessive amount of subprime mortgages, borrowers, on their part, underwrote loan contracts that they could not reimburse. Thus, the obvious question is what caused these people to sign up for mortgages that they could hardly pay back given their low income.

The fifth question is about the impact of the collapse of the mortgage market on the entire financial system. What surprised economists and institutions was the fact that the crisis in the mortgage market spread to the financial system as a whole. The mechanisms whereby mortgage delinquencies threatened to cause the collapse of the entire financial system must therefore be clarified.

The last question regards the impact of the financial crisis on the levels of income and employment. There is no automatic link between a financial crisis and a recession. Over the last 40 years, several financial crises did not produce significant effects on real variables. Hence, we need to shed light on the reasons why this financial crisis had such bad consequences for production and employment rates. Bernanke (2012) tackled this issue by underlining that the subprime mortgage crisis implied a destruction of financial wealth equal to approximately 7000 billion US dollars, which is comparable to the loss caused by the stock market crash that occurred in 2000, when the dot.com bubble burst. In that case, however, despite a decrease in financial wealth of approximately 8000 billion dollars, no significant downturn in income and 
employment was recorded. Consequently, it is imperative to understand why the bursting of the housing bubble had such devastating effects on income and employment rates. The next chapter will discuss the answers provided to these questions by mainstream economists.

\section{NOTES}

1. See, for example, King and Levine (1993); Levine (1997, 2002, 2004); Rajan and Zingales (1998, 2003a, 2003b, 2003c); Wurgler (2000); Stulz (2001); Gorton and Winton (2002); Wachtel (2003); Capasso (2004); and Fergusson (2006).

2. 'In our view ... in a perfect financial system, it will be the quality of the underlying assets or ideas that will determine whether finance is forthcoming, and the identity of the owner ... will be irrelevant. Because our focus is on how easy it is to raise finance without prior connections or wealth, our measures of financial development will emphasize the availability of arm's length market finance ... we adopt the Schumpeterian view that a critical role of finance is creative destruction, and this is possible only if there is a constant flow of capital into new firms and out of old firms' (Rajan and Zingales 2003b, pp. 9-10).

3. For a critical analysis of Rajan and Zingales's arguments see Bertocco (2008). 